九州大学学術情報リポジトリ

Kyushu University Institutional Repository

Zoning and resorption of plagioclase in a layered gabbro, as a petrographic indicator of magmatic differentiation

Hoshide, Takashi

Department of Geology and Mineralogy, Graduate School of Science, Kyoto University

Obata, Masaaki

Department of Geology and Mineralogy, Graduate School of Science, Kyoto University

http://hdl. hand le. net/2324/19880

出版情報: Earth and Environmental Science Transactions of the Royal Society of Edinburgh : Earth Sciences. 100 (Special Issue 1-2), pp.235-249, 2010-07. Cambridge University Press バージョン :

権利関係 : Copyright @ Royal Society of Edinburgh 


\title{
Zoning and resorption of plagioclase in a layered gabbro, as a petrographic indicator of magmatic differentiation
}

\section{Takashi Hoshide and Masaaki Obata}

\author{
Division of Earth and Planetary Sciences, Department of Geology and Mineralogy, Graduate School of Science, \\ Kyoto University, Kyoto, Japan 606-8502 \\ Email: hoshide@kueps.kyoto-u.ac.jp; obata@kueps.kyoto-u.ac.jp
}

\begin{abstract}
The Murotomisaki Gabbroic Intrusion is a sill-like layered gabbro emplaced in sedimentary strata of Tertiary age in southwest Japan. The zoning (including resorption structures) and the compositional variations of plagioclase from throughout the intrusion were studied, and it was found that the zoning pattern may be classified into four types, which may well correlated with the hosting rock types, the mode of occurrences and their stratigraphic positions in the intrusion. The plagioclase zoning was successfully decoded, and the sequence of events that took place during the magmatic differentiation was deduced and further interpreted in the context of a stratified basal boundary layer slowly ascending in a solidifying magma body. It was shown that various layered structures - modal layering, podiform gabbroic pegmatites and anorthositic layers - observed in the Murotomisaki Gabbro were formed within the moving basal boundary layer by flushing of $\mathrm{H}_{2} \mathrm{O}$-rich fluid and fractionated silicate melts from below. By the fluxing of hydrous fluids, plagioclase crystals preferentially dissolved and then melt fraction increased in the basal boundary layer. Under these circumstances, plagioclase-rich fractionated melts diapirically segregated from the crystal pile. Calcic plagioclases, which are out of equilibrium in the central part of the intrusion, may have originated from the basal boundary layer in this manner.
\end{abstract}

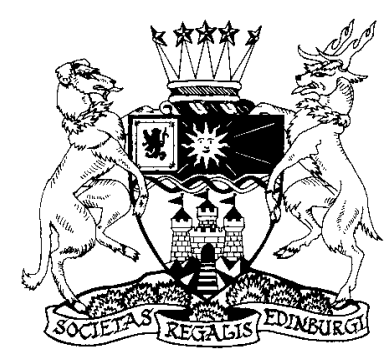

KEY WORDS: Anorthosite, boundary layer, crystal mush, diapir, fluid fluxing, magma chamber

Magma reservoirs are subjected to crystallisation and associated fractionation that are driven by the various physicochemical processes such as gravitational settling or flotation of crystals, compositional convection and compaction. As thermal gradient is created near the marginal zones of the magma reservoir (e.g. Brandeis \& Jaupart 1986; Turner et al. 1986; Marsh 1988; Tait \& Jaupart 1992), it is plausible that processes in the magmatic boundary layer play an important role in the magmatic differentiation after the settling of phenocrysts originally contained in the emplaced magma (Mangan \& Marsh 1992). Recent studies of crystal size and crystal number density of olivine by Hoshide et al. (2006a, b) identified the zone of crystal accumulation (AC subzone) and the zone of crystal growth (GR subzone). On the basis of the vertical variation and the numerical balance of crystal number density, they thought that crystal settling hardly occurred and some sort of processes involved in in situ crystallisation (crystal growth) were important in the magmatic differentiation after the major phase of crystal settling of olivine originally contained in the magma at the time of its emplacement. Furthermore, they emphasised the occurrence of anorthosites in the GR subzone and proposed a hypothesis that segregation and diapiric ascent of anorthositic crystal-mush played an important role in the formation of the GR subzone and thereby affected the entire magmatic evolution. The argument is largely based on the observed whole-rock compositional trends and plume-like occurrence of the anorthosites. The present paper takes a different approach to studying the magmatic processes in more detail, by looking at rock microstructure, particularly, the zonal structure of plagioclase from the Murotomisaki Gabbro. In contrast to ferromagnesian minerals like olivine or augite, plagioclase has the advantage of slow diffusion kinetics, so that original zoning formed during crystal growth, i.e., growth zoning, is well preserved in the crystals, thereby providing useful information on the sequence of events and temporal change of physico-chemical environment in the magmatic system.

Following the geological outline and petrographic description, analytical data on plagioclase zoning are presented, and it is shown that the zoning pattern is well correlated to the hosting rock types and the mode of occurrence. The zoning data and rock systematics will be interpreted in the context of a moving and crystallising boundary layer. It is emphasised that the zoned plagioclase may be used as a useful tracer of mass movement within a magmatic system under differentiation.

\section{Geological setting}

The Murotomisaki Gabbroic Intrusion (abbr. 'MGI') is a wedge-shaped, sill-like layered gabbro (up to $220 \mathrm{~m}$ thickness) located near Cape Muroto, Shikoku, Japan. This intrusion is emplaced nearly concordantly to bedded sandstone and mudstone of the Tertiary sediments (Shimanto Group), giving rise to contact metamorphism on both sides of the sill. The intrusion has been dated at $14 \mathrm{Ma}$ by the $\mathrm{Rb}-\mathrm{Sr}$ whole-rock isochron method applied to anatexites in the contact aureole produced by the hot magma emplacement (Hamamoto \& Sakai 1987). Regional geological and palaeomagnetic studies show that the intrusion was nearly horizontal when the magma was emplaced and solidified (Yajima 1972; Kodama et al. 1983; Kodama \& Koyano 2003). The intrusion, together with 
(c)

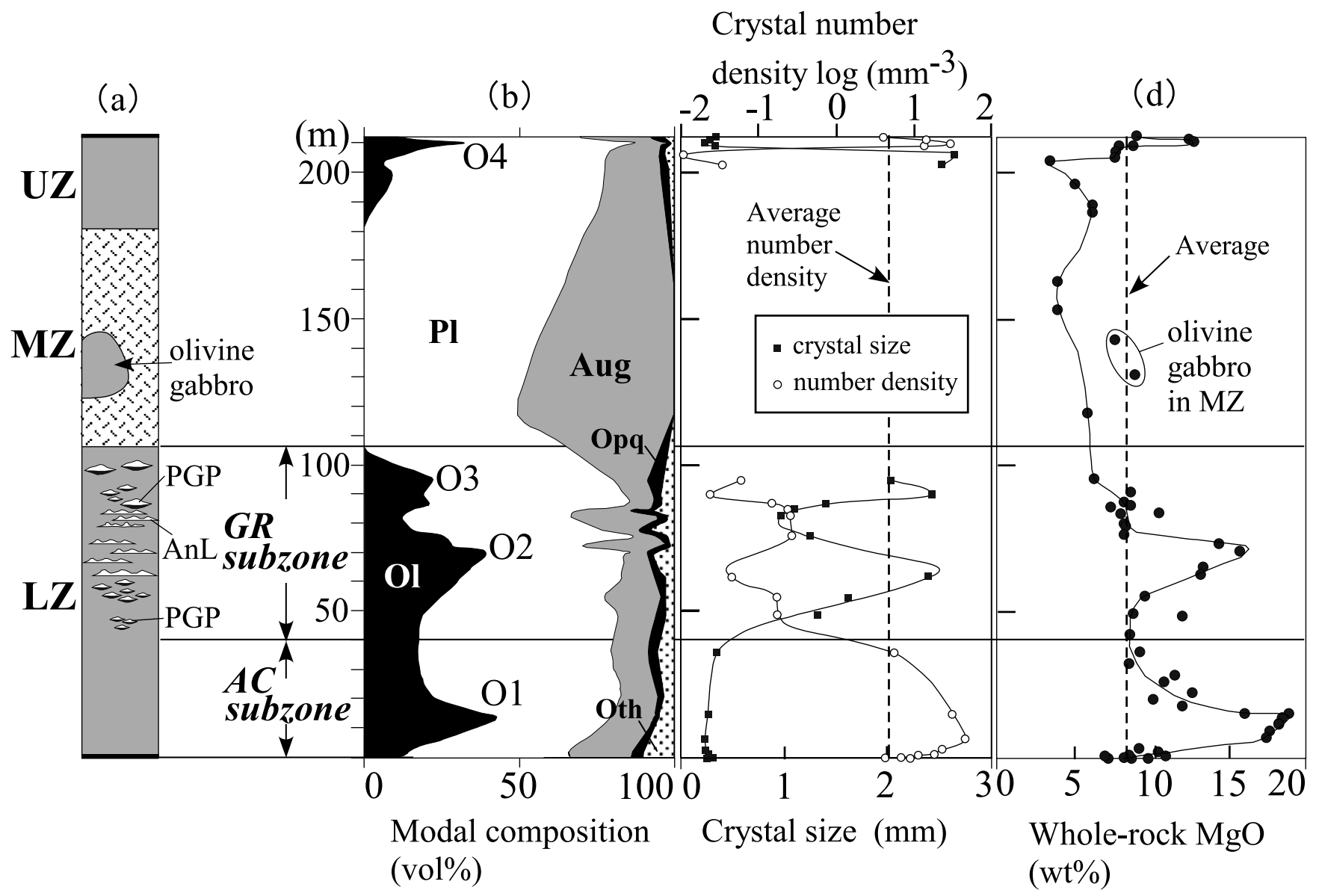

Figure 1 Lithological and compositional variations across the Murotomisaki Gabbroic Intrusion: (a) lithological variation; (b) modal variation; (c) crystal size and crystal number density of olivine; (d) whole-rock MgO content. Modified from Hoshide et al. (2006a). The crystal number density of olivine is shown in logarithmic scale. A broken line in (c) shows the level of average value of crystal number density of olivine of the intrusion. A broken line in (d) is the average value of the whole-rock MgO. Abbreviations: $\mathrm{LZ}=$ Lower Zone; MZ=Middle Zone; $\mathrm{UZ}=\mathrm{Upper} Z \mathrm{Zone} ; \mathrm{PGP}=$ podiform gabbroic pegmatite; $\mathrm{AnL}=$ anorthositic layer. $\mathrm{Pl}=$ plagioclase; $\mathrm{Ol}=$ olivine; Aug = augite; Opq=opaque minerals; Oth=other phases (hypersthene, biotite, hornblende and chlorite).

the surrounding sedimentary strata, was tilted by later tectonics by $60-70^{\circ}$ towards northwest. A near-complete crosssection of the intrusion is exposed along the sea coast (Fig. 1a).

\section{Petrographic subdivisions of the MGI}

According to the rock types and the mesoscopic layered structures observable in the field, the intrusion is divided into the following three major stratigraphic zones: the Lower Zone (LZ: about $105 \mathrm{~m}$ thick); the Middle Zone (MZ: about $75 \mathrm{~m}$ thick); and the Upper Zone (UZ: about $30 \mathrm{~m}$ thick) (Fig. 1a). The Lower Zone and the Upper Zone contain thin chilled margins of a few metres thick. The Lower Zone consists of fine- to medium-grained olivine gabbro and contains, in places, subordinate amounts of anorthositic layers (Fig. 2a) and podiform gabbroic pegmatites (Fig. 3). The Middle Zone mainly consists of coarse gabbro that is composed of augite and plagioclase, and characteristically lacks olivine. The Upper Zone consists of medium-grained olivine gabbro, whose textures are different from those of Lower-Zone olivine gabbros. Important petrographic features are summarised in Figure 1 and described below.

\subsection{The Lower Zone}

Using the olivine crystal number density (i.e., total number of crystals of olivine per unit volume of rocks), the Lower Zone has been subdivided into two subzones, the AC subzone and the GR subzone above (Fig. 1). The AC subzone comprises the lower $40 \mathrm{~m}$ and has crystal number density of olivine above the average of the whole intrusion, whereas the GR subzone $(40-100 \mathrm{~m})$ is less than the average. The crystal size of olivine and the presence or absence of the layered structures are clearly different between the AC and GR subzones. Therefore, the field occurrence and petrography are described separately for each subzone.

2.1.1. The AC subzone. The AC subzone appears uniform in the field; the grain size increases gradually upwards from the lower contact. The chilled margin, within a few $\mathrm{cm}$ from the contact, is very fine-grained, containing a few microphenocrysts of olivine (up to $8 \mathrm{vol} \%$, average grain size $0.25 \mathrm{~mm}$ ) and plagioclase $(\sim 1-3 \mathrm{vol} \%$, average grain size $0 \cdot 1 \mathrm{~mm})$ in a darkcoloured matrix (probably a devitrified glass) that contains small skeletal or swallow-tailed crystals of plagioclase (average grain size $10 \mu \mathrm{m})$ (Fig. 4a).

Olivine increases rapidly in both mode and number density with distance from the lower contact, and the maximum is observed at ca. 15 metres (peak O1) before decreasing (Fig. 1b, c). Crystal size of olivine, on the other hand, remains nearly constant. Plagioclase monotonically increases in size, which results in an overall upward-coarsening of rocks.

The texture is typically poikilitic. Euhedral to subhedral plagioclase partially encloses euhedral olivine. Anhedral augite 

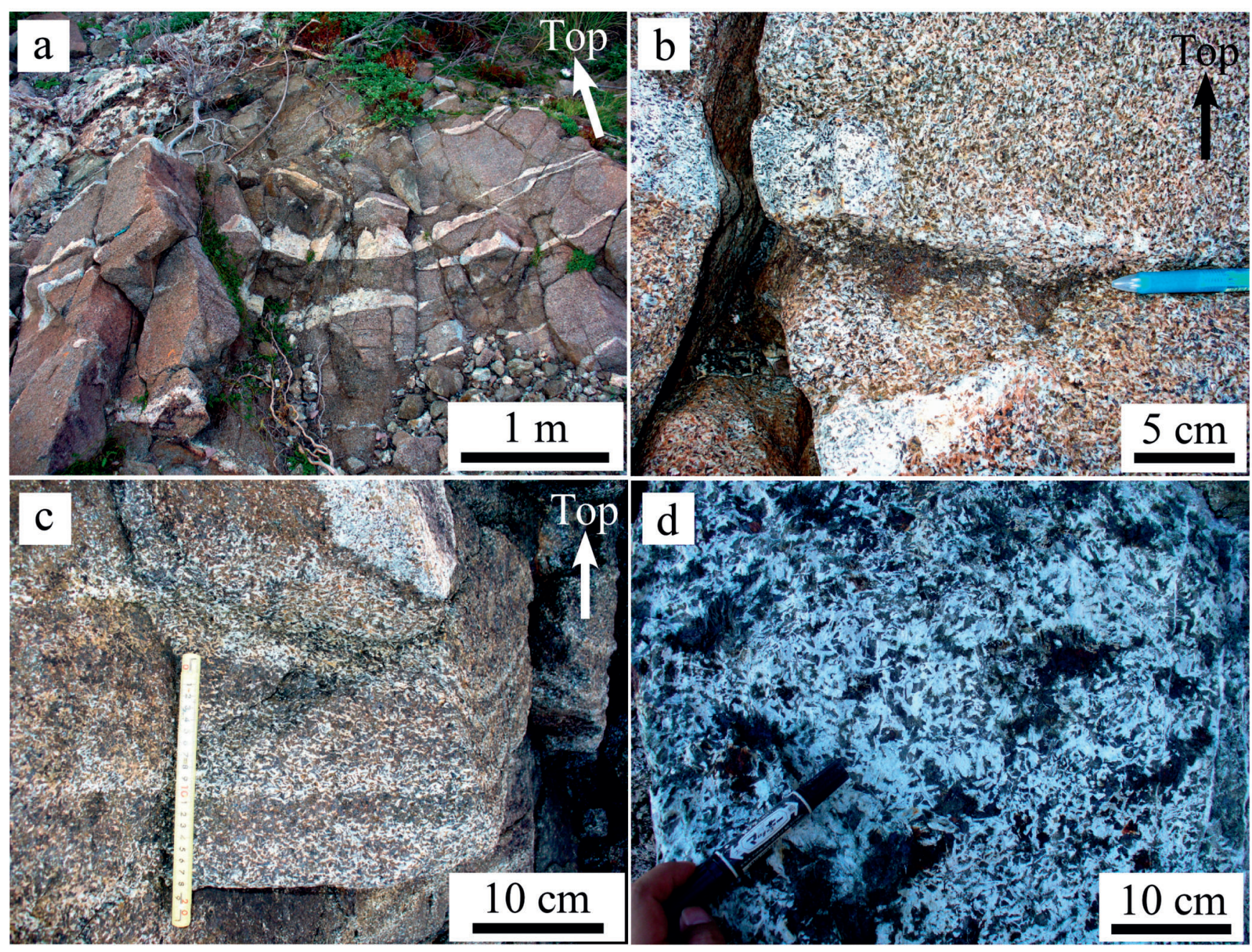

Figure 2 Field photographs of the Murotomisaki Gabbro: (a) Anorthositic layers (AnL, light coloured) in the olivine-gabbro matrix of the GR subzone (approximately $78 \mathrm{~m}$ from the bottom). Note a flat bottom and a wavy upper surface. Arrow indicates the top of the sill; (b) closeup of (a). Thin mafic selvage attached to the base of an anorthositic layer. The layer trails down in a wavy form; (c) Modally graded layering in the lowermost part of the GR subzone (approximately $40 \mathrm{~m}$ from the bottom); (d) Field photograph of a coarse gabbro in the Middle Zone (approximately $150 \mathrm{~m}$ from the bottom) showing a mesoscopic patchy structure, consisting of melanocratic patches rich in augite and opaque mineral and leucocratic plagioclase-rich matrix.

encloses olivine and plagioclase or occupies their interstices (Fig. 4b). Plagioclase usually has a euhedral calcic core nearly constant in An-content and this An-content decreases continuously towards the rim (Fig. 5a). The plagioclase cores often show oscillatory zoning and have thin edges of even more calcic composition than the core. More details of the zonal structures are given in the next section.

The olivine crystals often contain small polycrystalline clots (several tens $\mu \mathrm{m}$ in size) consisting of pargasitic amphibole, hypersthene and biotite that are hereafter called 'amphibole clots' (Fig. 5d). Many clots are nearly-round, but some have the form of a 'negative crystal' of the host olivine. The morphology and the occurrence suggest that these clots probably represent solidified hydrous silicate melt entrapped in growing olivine crystals at magmatic stages.

2.1.2. The GR subzone. The GR subzone is lithologically more variable. The observed modal range is $12-40 \%$ olivine, $5-30 \%$ augite and $52-65 \%$ plagioclase; olivine grain size varies from $1.0 \mathrm{~mm}$ to $2.5 \mathrm{~mm}$. Compositional layering is more developed than in the AC subzone (Fig. 1). This zone contains abundant layers of anorthosite (Fig. 2a) and lenticular pods of gabbroic pegmatite (Fig. 3a, b). There are two modal peaks of olivine in the host gabbro $(\mathrm{O} 2$ and $\mathrm{O} 3)$, where average grain size of olivine is maximum. These two peaks coincide in position with the minimum peaks of olivine number density. In addition, peak $\mathrm{O} 2$ coincides with the maximum whole-rock $\mathrm{MgO}$ content (Fig. 1).

In olivine gabbros of the GR subzone, euhedral to subhedral plagioclase partially encloses euhedral olivine in common with that of the AC subzone, but olivines are larger and have lower number density than in the AC subzone and thus the texture is not poikilitic. Around the peak O2, augite is less abundant (below $10 \mathrm{vol} \%$ ) and fills interstices between cumulus olivine and plagioclase (Fig. 4c). Gabbros around the peak $\mathrm{O} 2$ have modal ratios of olivine/plagioclase universally higher than those around peak O3. Around peak O3, olivine crystals are large and irregularly shaped and typically enclose plagioclase. The amphibole clots in the olivine crystals (Fig. 5d) are more abundant and are larger in size $(\sim 1 \mathrm{~mm})$ than those of the AC subzone. The amphibole clots also occur at interstices of aggregates of olivine crystals.

A fine-scale rhythmic layering due to modal variation of plagioclase, olivine and augite (with typical wave length around $10 \mathrm{~cm}$ ) locally develops in a lowermost part of the GR subzone (the 'compositional banding' of Yajima 1972) (Fig. $2 \mathrm{c})$. The felsic layers show weak shape-preferred orientations of plagioclase parallel to the layering. The mode of the layering is vertically asymmetric, that is, a felsic layer gradually changes 
into the overlying mafic layer, but sharply into the underlying one. The modally-layered portion is more coarse-grained than the surrounding massive and more homogeneous parts at the same level. Plagioclase varies in the modal amount by $15 \%$ to $60 \%$ in this layering. Plagioclase and olivine are cumulus phases, and augite occurs at interstitial positions. Plagioclase crystals have calcic cores, the shapes of which are slightly rounded or corroded compared to those in non-layered gabbros. In the felsic layers, their calcic cores are larger than those in the mafic layers.

2.1.3. Bimodal occurrence of anorthosites (in the 'GR subzone'). Two types of anorthosite occur in the GR subzone. One type forms a constituent part of podiform gabbroic pegmatites (Fig. 3a, b); the other forms individual mediumgrained layers (Plagioclase grain size: $2 \mathrm{~mm}$ in length; $\sim 50 \mathrm{~cm}$ thick) without a pegmatitic part (Fig. 2a). The anorthositic layer is abundant at the $70-80-\mathrm{m}$ horizon, around the $\mathrm{O} 2$ peak, whereas the podiform gabbroic pegmatite is more abundant just below and above this horizon (Fig. 1a).

Podiform gabbroic pegmatite. The podiform gabbroic pegmatites are lenticular in shape, oriented sub-parallel to the layering and vary in thickness from a few $\mathrm{cm}$ to $2 \mathrm{~m}$ (Fig. 3). They form clusters of several metres to several tens of metres in size (Fig. 3c). Each pod typically has an internal layered structure consisting of an anorthositic roof, a pegmatitic filling, and a picritic floor (Fig. 3b).

The anorthositic roof is medium- to coarse-grained (plagioclase grain size, about $3-10 \mathrm{~mm}$ in length) and has strong shape fabrics of plagioclase; euhedral plagioclase crystals are aligned sub-horizontal, parallel to the lower and the upper boundaries. The upper boundary of the anorthositic roof against the host olivine gabbro is often wavy and the plagioclase crystals are aligned parallel to the wavy boundary. This wavy structure has locally developed into plume-like, 'diapiric structure', implying a gravitational fluid-dynamic instability being developed at magmatic stages (Fig. 3d). Globular small masses of anorthosite (about $10 \mathrm{~cm}$ in diameter) occur above these plumes (Fig. 3d, f). The anorthositic roof and the 'globular' anorthosite masses contain abundant clots of amphibole of a few $\mathrm{mm}$ in diameter (Fig. 3e). Near the margin of the globular anorthosite masses plagioclase crystals are also aligned roughly parallel to their boundaries.

Microscopically, the anorthosite in the roof has an ophitic texture, consisting of euhedral plagioclase crystals (60$80 \mathrm{vol} \%$ ) enclosed in large augite crystals (20-35 vol\%) (Fig. $4 \mathrm{~g}$ ). Some plagioclase crystals show undulose extinction, implying plastic deformation of crystals. They also contain small amounts of calcite, apatite, titanite and allanite that occur in the interstices of euhedral plagioclase. Other accessory phases are ilmenite, titaniferous magnetite and sulfides. Intergrowths of ilmenite with titanite or titaniferous magnetite are common in the anorthositic roofs, whereas these oxides occur as independent grains in the host olivine gabbro.

The pegmatitic filling is very coarse-grained and consists of euhedral plagioclase (about $1-4 \mathrm{~cm}$ in length; $\sim A n_{30-50}$ ) and interstitial augite. Plagioclase crystals are aligned nearly perpendicular to the sharp boundary with the anorthositic roof (Fig. 3a).

The picritic floor is also medium-grained (olivine grain size: about $2-3 \mathrm{~mm}$ in length) and consists of euhedral olivine $(40 \sim 70 \mathrm{vol} \%)$ and interstitial plagioclase and augite (Fig. $4 \mathrm{~h}$ ). Olivine in the picritic gabbro in the floor is identical in composition to that in the host olivine gabbro $(\mathrm{Mg} \#=60-65)$.

An outstanding feature is the invariability of the sequence of the internal layering with the anorthositic roof always on the top and the picritic floor on the bottom. The volume proportion of these three parts varies; the anorthositic roof may be very thin in some podiform pegmatites (Fig. 3b), whereas the picritic floor is minor or even missing in others (Fig. 3a).

Anorthositic layers. Anorthositic layers vary in thickness between $10 \mathrm{~cm}$ and $1 \mathrm{~m}$ and are oriented parallel to the compositional layering. The upper boundary to the host gabbro is wavy, like that of the anorthositic roof of the podiform gabbroic pegmatite, and the lower boundary is flat (Fig. 2a). Anorthosite has strong crystal shape fabrics, with plagioclase crystals aligned parallel to the wavy contacts (see also fig. 3B in Hoshide et al. 2006b). Some anorthositic layers have thin discontinuous basal layers of medium-grained mafic rocks (olivine grain size: about $2-3 \mathrm{~mm}$ in length), like the picritic floor of the podiform gabbroic pegmatite, implying its genetic link with podiform gabbroic pegmatites (Fig. 2b). The texture and rock composition of the anorthositic layers are very similar to the roof anorthosite.

\subsection{The Middle Zone}

The Middle Zone lacks obvious layering, but characteristically contains patchy mafic domains of a few to tens of centimetres in size (Fig. 2d). Euhedral plagioclase crystals included in large augite grains (up to several centimetres in size) form an ophitic texture (Fig. 4d, e). Olivine is generally absent except in one sample (at the 152-m level). The olivine in this sample is very iron-rich and shows a reverse zoning from an Fe-rich core $(\sim$ Fo37) to an Fe-poor rim ( $\sim$ Fo43). Hydrous minerals, such as hornblende, biotite and prehnite, occur as interstitial phases, as well as in the 'embayments' of the calcic cores of plagioclase. Some rocks from the lower part of the Middle Zone have large plagioclase crystals that fill interstices of euhedral to subhedral augite crystals. A large block (15 m across) of medium-grained olivine gabbro occurs within the Middle Zone. The boundary between the block and the surrounding coarse gabbro is not clear because of poor exposure.

\subsection{The Upper Zone}

Olivine gabbro, which consists of olivine, plagioclase and augite, is the main rock type in this zone. Starting from the upper contact, olivine rapidly increases downward in the modal abundance and in crystal number density, marking a sharp peak (O4) at about the 210-m level (2 m below the upper contact; Fig. 1). The olivine grain size near the contact is about the same as that of AC subzone in the Lower Zone, but increases rapidly below the modal peak $\mathrm{O} 4$ and reaches a maximum at about the 206-m level (Fig. 1c). Around peak O4 there is a horizon that contains abundant spherulitic clots of hornblende aggregate (about $0 \cdot 2 \mathrm{~mm}$ to $3 \mathrm{~cm}$ in diameter).

Although the host rocks are mineralogically similar to the olivine gabbros in the Lower Zone, the texture is different. Whilst the plagioclase is euhedral to subhedral, olivine and augite are irregular in shape and fill the interstices of plagioclase crystals in the Upper Zone. Some plagioclase crystals contain subhedral to anhedral calcic cores nearly constant in An-content and the boundary between the calcic core and the sodic mantle is rather sharp, marking a compositional gap as described in next section. Other grains in the same sample do not contain such distinct calcic cores, but show more gradual normal zoning. Plagioclase crystals become aggregated and form cancellous plagioclase-rich networks at the centimetrescale and are oriented in the same direction in the networks. In the networks or clusters (a few centimetres scale), plagioclase crystals show undulose extinction and deformation twins, implying that they have been plastically deformed (Fig. 4f). 


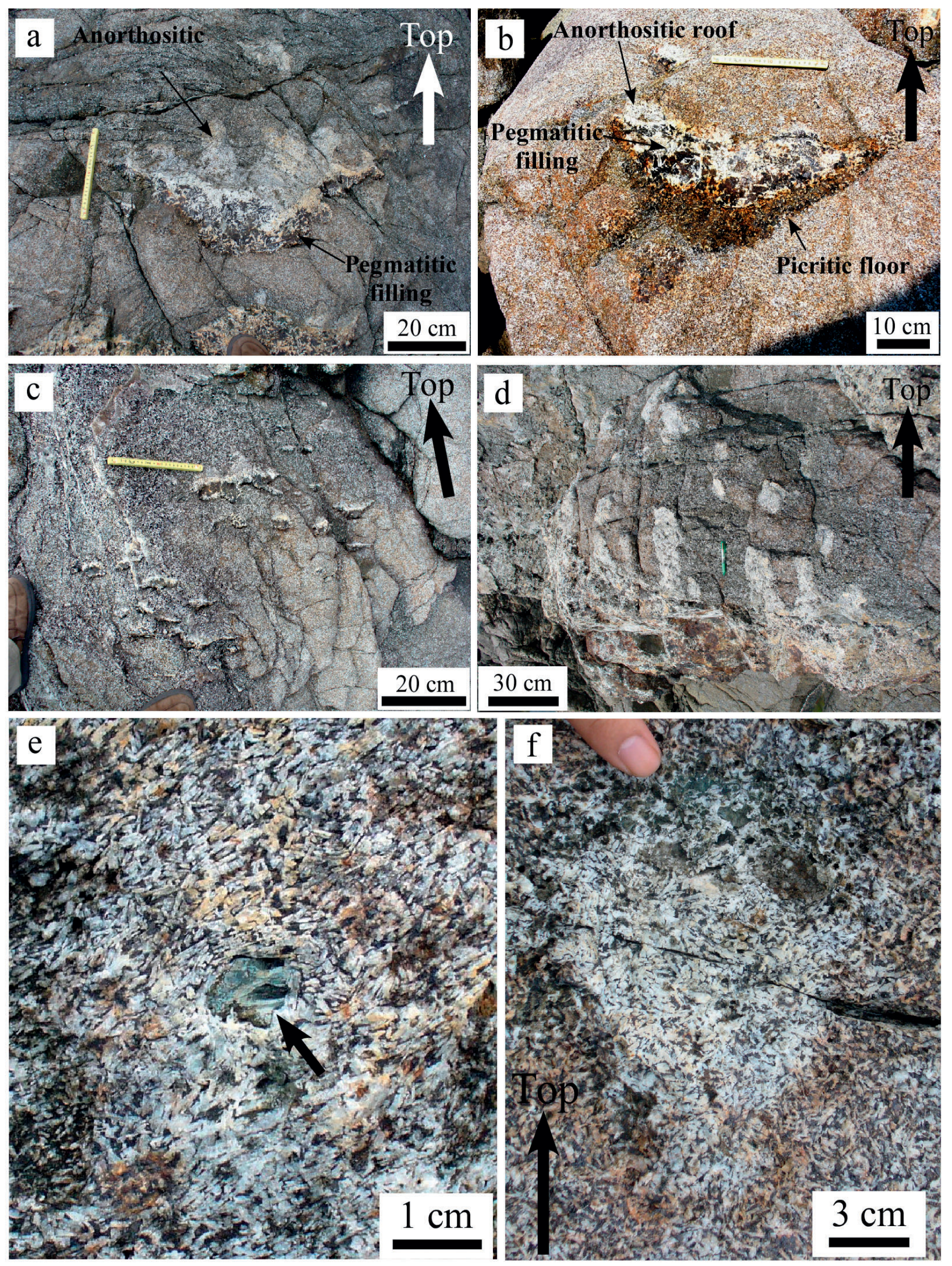

Figure 3 Photographs of podiform gabbroic pegmatites in the GR subzone. Arrow in each photograph indicates the top of the sill: (a) and (b) podiform gabbroic pegmatite (at approximately $40 \mathrm{~m}$ from the bottom); (c) Swarming podiform gabbroic pegmatites (at approximately $40 \mathrm{~m}$ from the bottom); (d) plume-like structure of anorthosite developed on the roof of podiform gabbroic pegmatite (approximately $50 \mathrm{~m}$ from the bottom); (e) An amphibole clot (arrow) in an anorthositic roof. Note plagioclase crystals aligned parallel to the outline of the amphibole clot; (f) A globular mass of anorthosite lying just above the anorthositic roof of the podiform gabbroic pegmatite. The anorthositic mass contains abundant hornblendes at the top of the mass (pointed by a finger) 


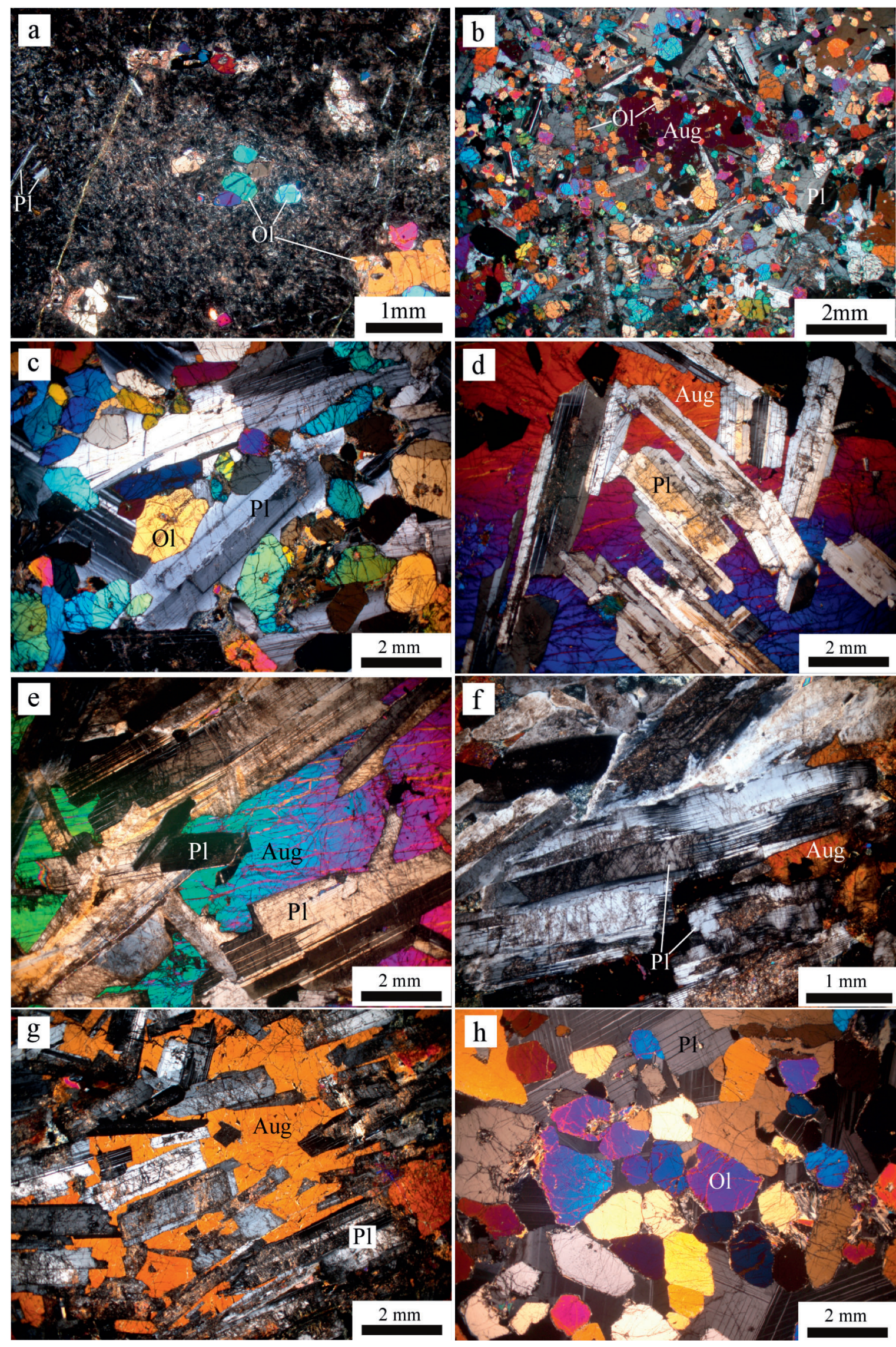

Figure 4 Photomicrographs of the Murotomisaki gabbroic rocks: (a) the lower chilled margin, sample LCM32 (just contact with the country rocks); (b) Lower-Zone picritic gabbro, sample 91080503 (AC subzone, $15 \mathrm{~m}$ from the bottom, around O1 in Fig. 1); (c) Lower-Zone olivine gabbro, sample 91080706 (around O2 in Fig. 1, at $71 \mathrm{~m}$ ); (d) Middle-Zone coarse gabbro, sample 91080906 (152 m from the bottom); (e) Middle-Zone coarse gabbro, sample 91081003 (162 m from the bottom); (f) Upper-Zone, sample 92081007 (203 $\mathrm{m}$ from the bottom). Plastically-deformed plagioclase crystals showing undulose extinction; (g) anorthositic roof of the podiform gabbroic pegmatite, sample 06050402 (53 m from the bottom); (h) picritic floor of the podiform gabbroic pegmatite, sample 06080603 (60 $\mathrm{m}$ from the bottom). Abbreviations for minerals are the same as in Figure 1. 

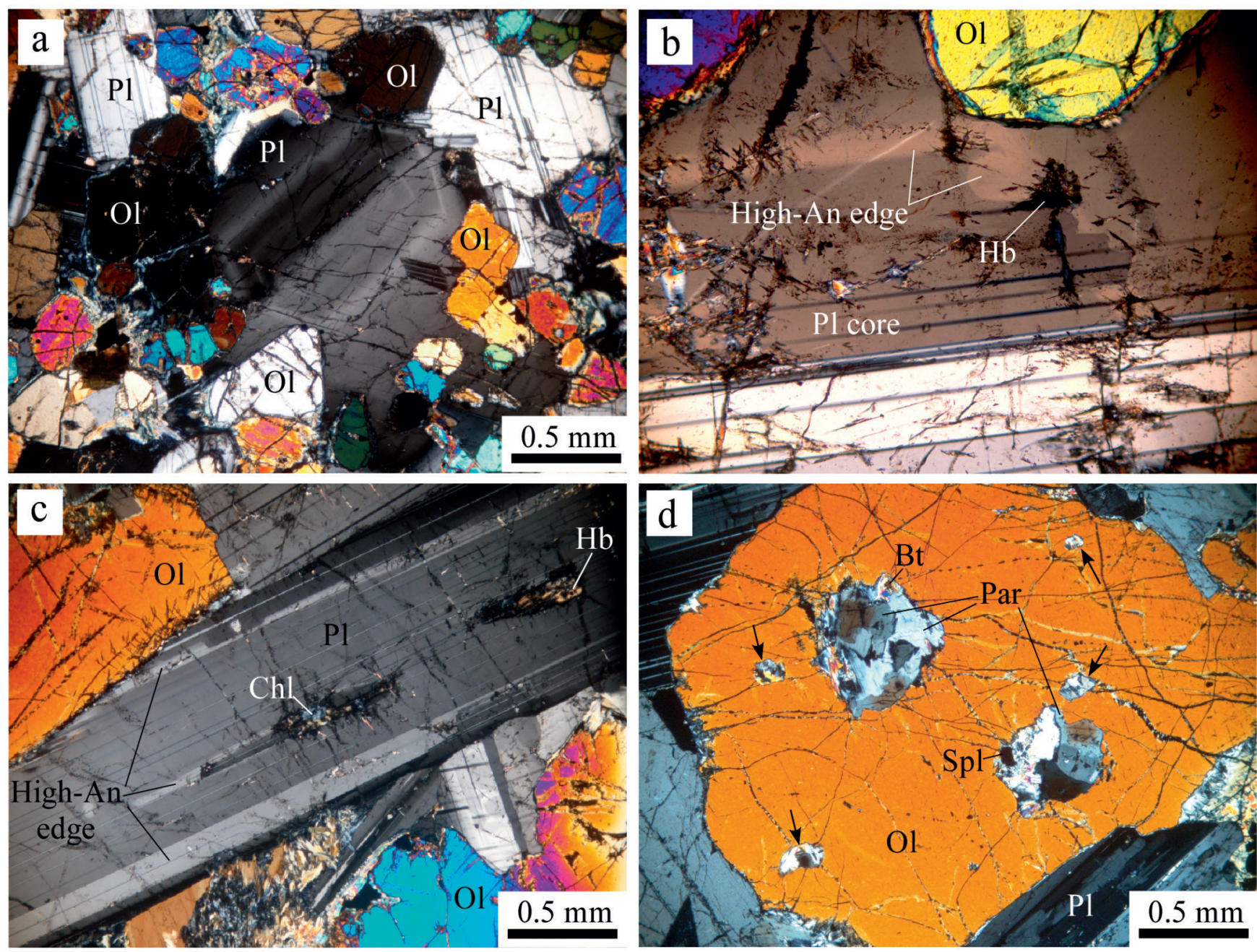

Figure 5 (a) Oscillatory zoned plagioclase of the Lower-Zone picritic gabbro (sample 91080503). (b) A high-An edge (bright part) occurring around the calcic core of plagioclase in the GR subzone. Note that boundary between the core and the edge is rough. (c) Embayments in the calcic cores that are filled with sodic plagioclase associated with small amount of hornblende, augite and chlorite. Thin small high-An edges are developed surrounding the embayment. (d) 'Amphibole clots' included in an olivine crystal of a Lower-Zone olivine gabbro. Abbreviations: $\mathrm{Bt}=$ biotite; $\mathrm{Par}=$ pargasite; $\mathrm{Spl}=$ spinel. Abbreviations for the other minerals are the same as in Figure 1.

\section{Plagioclase zoning and its stratigraphic variations}

\subsection{Plagioclase zoning}

The plagioclase-zoning pattern was studied in details using an EDS microprobe at Kyoto University (Hitachi S3500H scanning electron microscope equipped with an EDAX energy dispersive analytical system) and a WDS microprobe at Kobe University (JEOL JXA8900). The accelerating voltage and beam current were maintained at $20 \mathrm{kV}$ and $500 \mathrm{pA}$ at Kyoto, and at $15 \mathrm{kV}$ and $12 \mathrm{nA}$ at Kobe.

It was confirmed that the calcic core of plagioclases from the Lower Zone is nearly constant in An-content throughout the core (see below). Some plagioclase cores from the lower part of the Lower Zone (i.e. the AC subzone) show oscillatory zoning (Fig. 5a), but the oscillation tends to fade away in the upper parts. Olivine crystals are typically in contact with the outlines of the calcic cores of plagioclases (Figs 4c, 5a, 6a). The calcic core is typically surrounded by a narrow edge (of $20-100 \mu \mathrm{m}$ width) of even more calcic composition $(\sim$ An72-80). This narrow edge of high An-content is referred to as 'high-An edge' hereafter (Figs 4c, 5a-c, 6a). The outlines of the calcic cores (i.e. the boundaries between the core and the high-An edge) are nearly straight and smooth (Fig. 4c), but some of them are rough or wavy (Fig. 5b). Across the core to the high-An edge, the An-content abruptly increases and then rapidly decreases back to about the same An-content level as the core with a steep gradient (Fig. 7a). Furthermore, the gradient discontinuously changes and then the An-content continuously decreases outwards with a gentler gradient. This outer marginal zone of the gentle compositional gradient is referred to as 'mantle' hereafter. This zoning pattern, which is typically observed in the host olivine gabbros, is designated as Type A (Fig. 8). Locally, there are embayments or 'pools' in the calcic cores of the Type A plagioclases that are filled with distinctly sodic plagioclase $(\sim$ An50) associated with small amount of augite and hornblende (Figs 5c, 6a). In some cases, narrow high-An edges surrounding the calcic cores are developed surrounding the embayment (Fig. 5c). Small grains of hydrous phases such as amphibole and chlorite occur in the embayments of the calcic cores (Fig. 5c) or along the boundaries between the calcic cores and the high-An edges (Fig. 5b). Such embayments or resorption structures are more pervasive and better developed in the anorthosites as described below.

The plagioclases in the anorthosites, both from the roofs of the podiform gabbroic pegmatites and the anorthositic layers, have similar zonal structure, but this differs from that of the host gabbros. They have the calcic cores nearly constant in 


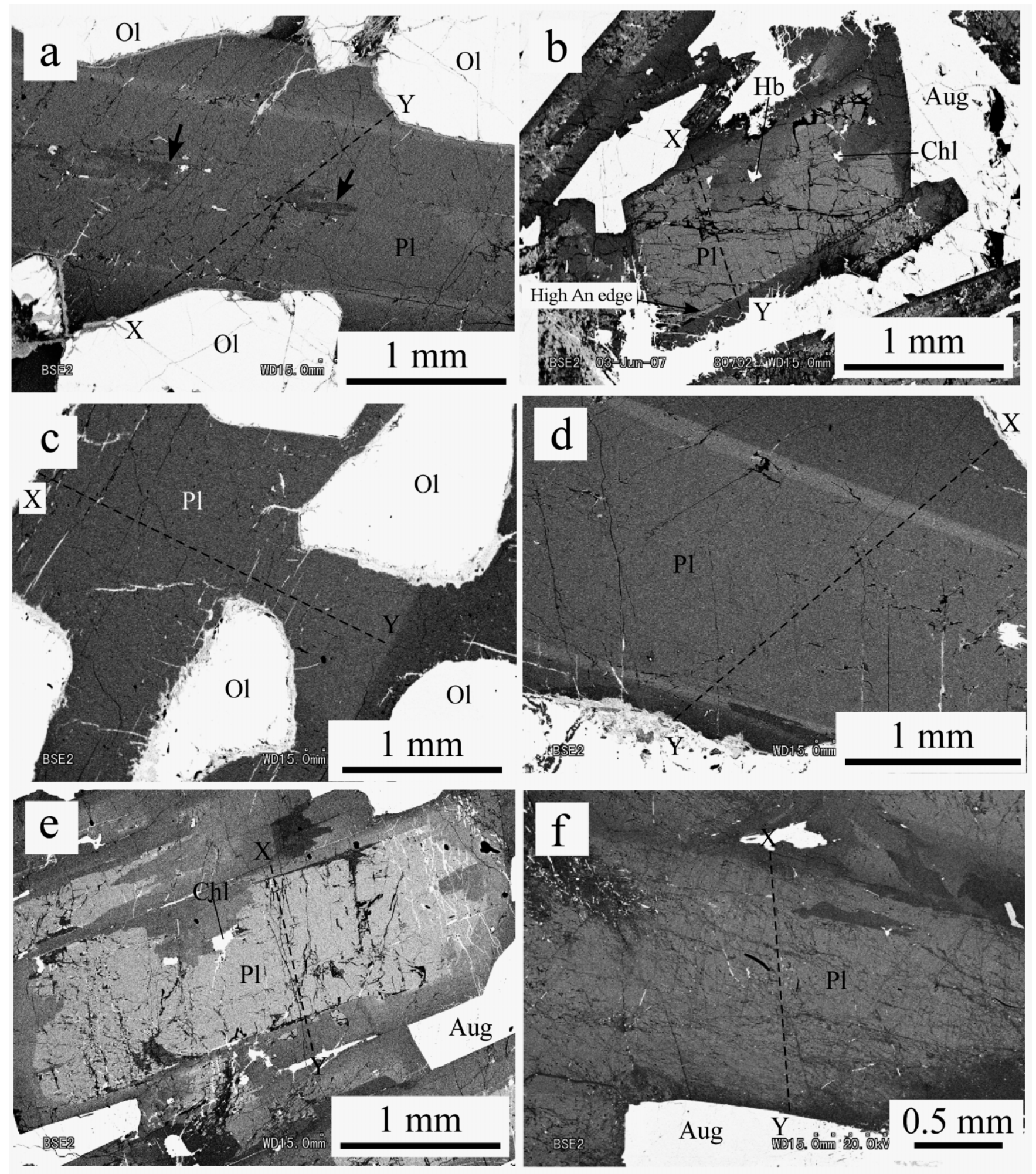

Figure 6 Back scatter electron images of plagioclase crystals from various rock types of the Murotomisaki Gabbro. Dashed lines in the BSE images indicate the zoning profile sections in Figure 7: (a) Plagioclase from the Lower Zone (GR subzone, $71 \mathrm{~m}$ from the bottom, sample 92080706); (b) Plagioclase from the anorthositic roof of the podiform gabbroic pegmatite ( $45 \mathrm{~m}$ from the bottom, sample 06080703). The narrow high-An edge (arrow) is partly retained where the calcic core is not embayed; (c) Plagioclase from the picritic floor of the podiform gabbroic pegmatite; (d) Plagioclase from the modal layering (about $40 \mathrm{~m}$ from the bottom, sample ML1); (e) Plagioclase from the coarse gabbro in the Middle Zone (152 $\mathrm{m}$ from the bottom, sample 91080906); (f) Plagioclase from coarse gabbro in the Middle Zone (162 m from the bottom, sample 91081003). Abbreviations: $\mathrm{Hb}=$ hornblende; $\mathrm{Chl}=$ chlorite. Abbreviations of the other minerals are the same as in Figure 1.

An-content, which are partly resorbed (Fig. 6b). The resorption structure is more conspicuous in the anorthosites than in the host gabbros. The high-An edges partly surround the outlines of the calcic cores. The An-content abruptly decreases from the core (or the high-An edge) to the mantle, marking a distinct compositional gap (typically by $15-20 \mathrm{An} \%$ ) between the core and the mantle (Fig. 7b). Throughout the mantle, the An-content gently decreases outwards. This type of zoning is designated as 'Type B' (Fig. 8). The sodic plagioclase that fills the embayments of the calcic core often includes small grains 

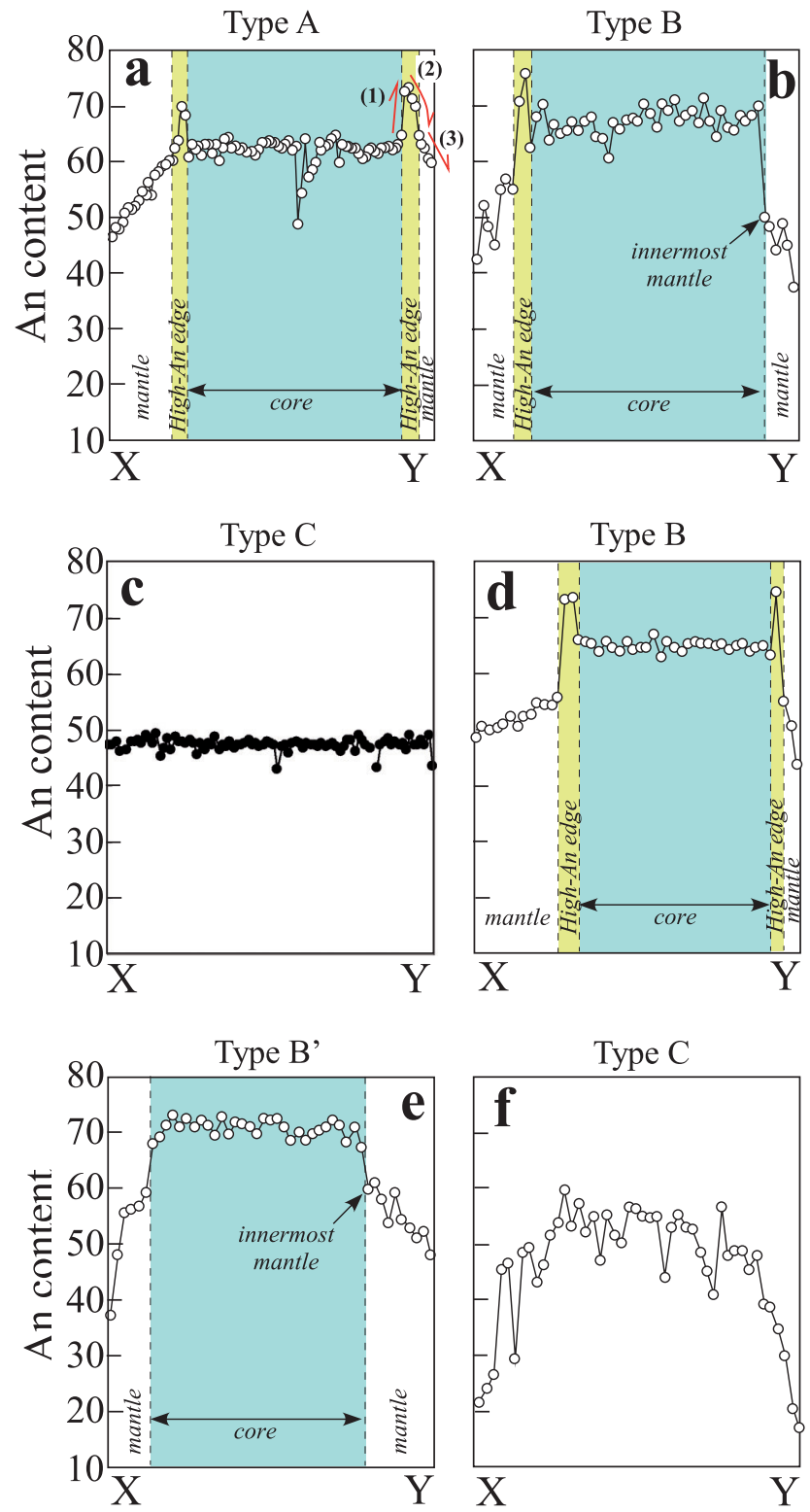

Figure 7 Zoning profiles of plagioclase crystals from various rock types of the Murotomisaki Gabbro: (a) Plagioclase from the Lower Zone (GR subzone, $71 \mathrm{~m}$ from the bottom, sample 92080706). Across the core to the high-An edge, (1) the An-content abruptly increases and then (2) rapidly decreases back to about the same An-content as the core with a steep gradient and then (3) continuously decreases outwards with gentler compositional gradients; (b) Plagioclase from the anorthositic roof of the podiform gabbroic pegmatite $(45 \mathrm{~m}$ from the bottom, sample 06080703). The 'innermost mantle' shows the right outside of the calcic core; (c) Plagioclase from the picritic floor of the podiform gabbroic pegmatite; (d) Plagioclase from the modal layering (about $40 \mathrm{~m}$ from the bottom, sample ML1); (e) Plagioclase from the coarse gabbro in the Middle Zone $(152 \mathrm{~m}$ from the bottom, sample 91080906); (f) Plagioclase from coarse gabbro in the Middle Zone (162 $\mathrm{m}$ from the bottom, sample 91081003).

of ferrohornblende, ferro-augite, Fe-chlorite, ilmenite and titaniferous magnetite (Fig. 6b).

Plagioclase in the picritic floors of the podiform gabbroic pegmatites is more sodic $\left(\mathrm{An}_{43-55}\right)$ than that in the host olivine gabbros and the anorthosites (Fig. 7c). They show nearly constant An-content throughout the crystal but locally have narrow sodic rims without calcic cores like those of Types A or B (Fig. 6c). This zoning type is designated as 'Type C' (Fig. 8). The An-content of the core is comparable to that of the innermost mantle (i.e., next to the high-An edge) of the Type B plagioclase from the anorthositic roof within the same podiform gabbroic pegmatites (Figs 7b, 9).
Plagioclases from the modal layering (in the lowermost part of the GR subzone) also have the resorbed calcic cores, like those from the anorthosites of the podiform gabbroic pegmatites and the anorthositic layers. The cores are partly surrounded by the high-An edge and have a compositional gap with a distinctly sodic mantle (therefore Type B) (Fig. 6d). However, the calcic cores are less resorbed and the compositional gap between the core and the mantle is smaller (10$15 \mathrm{An} \%$ ) than those of the adjacent anorthosites (Figs 6d, 7d). The plagioclase from the modally layered gabbros is, therefore, regarded to be intermediate in terms of zoning and composition between those from the host gabbros and from the anorthosites.

Middle-Zone and Upper-Zone gabbros contain at least two types of plagioclase crystals with distinct zoning patterns. One type has irregular-shaped calcic core with nearly constant An-content surrounded by distinctly sodic mantles (Figs 6e, $7 \mathrm{e})$. Some of them can be classified into Type B, but others lacks the high-An edges. Therefore, the latter zoning pattern is termed as Type $\mathrm{B}^{\prime}$ to distinguish it from Type B (Fig. 8). It is possible that the high-An edges have been lost by extensive resorption, in which case Type $\mathrm{B}^{\prime}$ is simply a derivative from Type B. The other type plagioclase is more sodic in composition and does not contain calcic cores with constant Ancontent (Figs 6f, 7f). It shows normal and gradual zoning and, therefore, is classified as Type C (Fig. 8). In summary there is a good correlation between the zoning type and host the rock type as illustrated in Figure 8 and Table 1. The Lower-Zone olivine gabbro is dominated by Type A, the anorthosites from the Lower Zone are characterised by Type B zoning, whilst both the picritic floor of the podiform gabbroic pegmatite and the mafic part of the modal layering show Type $\mathrm{C}$. The Middle and Upper Zones contain two types, B and C mixed together, and never contain Type-A plagioclase.

\subsection{Stratigraphic variation of plagioclase composition}

Figure 9 shows a summary of the stratigraphic variation of the An-content of the plagioclase obtained by the microprobe analysis from the host gabbros and the anorthosites (both the anorthositic roofs of the podiform gabbroic pegmatites and the anorthositic layers).

In the AC subzone, the An-content of the core from the host gabbro is nearly constant (in the range of An 70-73), whereas in the upper half of the Lower Zone (i.e., the GR subzone), it gradually decreases with increasing stratigraphic height, from An 73 to about An 62. Note that the plagioclase core composition from the anorthosites is nearly the same as those from host olivine gabbro, except one sample at the 78-m level (No. 91040602). This exceptional anorthositic layer has about 5 An mole \% higher cores than those from its host gabbro. The An contents of the high-An edges of the plagioclase core, which are constantly about 10 An \% higher than the core values, also decrease with increasing stratigraphic height, again with the exception of the anorthosite layer mentioned above. The An content of the innermost parts of the plagioclase mantles (marked 'im' in Fig. 9), just outside the high-An edge, (Type B and $\mathrm{B}^{\prime}$ plagioclase) is about $15-20$ mole \% lower than those of the cores and it also roughly decreases upward.

In the Middle-Zone coarse gabbros, there is no clear correlation between the core composition and the stratigraphic height, although the data are sparse in this zone. Out of six samples analysed, four samples contain only plagioclase crystals of Type $\mathrm{C}$ zoning and their cores are all less calcic (An 50-69) than the Lower-Zone core compositions. The other two samples (at 152 and $153 \mathrm{~m}$ from the bottom) contain plagioclase of Type B or B' zoning. These samples are very heterogeneous with respect to core composition, showing wide 


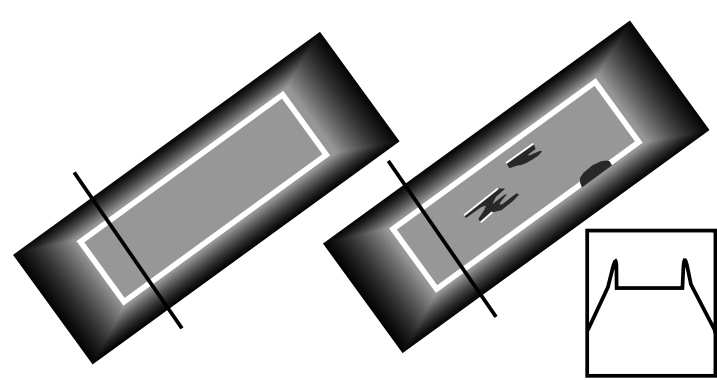

Type A

Euhedral calcic core bearing (sporadically resorbed)

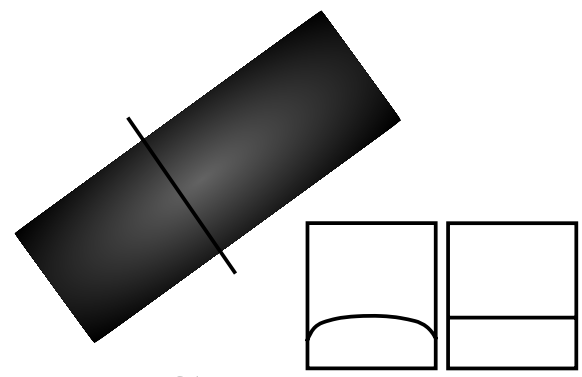

Type C

No calcic core

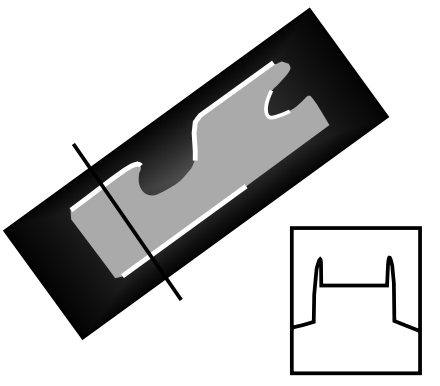

Type B

Partly resorbed calcic core bearing (with high-An edge)

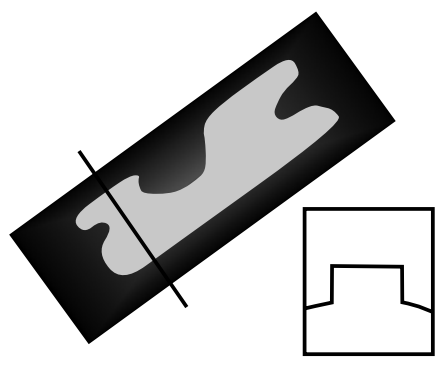

Type B'

Partly resorbed calcic core bearing (without high-An edge)

Figure 8 Schematic illustrations of plagioclase compositional zoning patterns observed from the Murotomisaki Gabbro. Each picture of zoned plagioclase is accompanied by a schematic drawing of the line profile.

Table 1 Four types of plagioclase compositional zoning patterns correlated with different rock types of the Murotomisaki Gabbro.

\begin{tabular}{|c|c|c|c|c|c|c|c|c|}
\hline \multicolumn{7}{|c|}{$\mathrm{LZ}$} & \multirow[b]{3}{*}{ MZ } & \multirow[b]{3}{*}{$\mathrm{UZ}$} \\
\hline \multirow[b]{2}{*}{ Host gabbro } & \multicolumn{2}{|c|}{ Modal layering } & \multicolumn{3}{|c|}{ Podiform gabbro pegmatite } & \multirow[b]{2}{*}{ Anorthositic layer } & & \\
\hline & felsic part & mafic part & roof & pegmatite & floor & & & \\
\hline
\end{tabular}

\begin{tabular}{llllllll}
\hline Type A & $\circ$ & & & & & & \\
\hline Type B & $\Delta$ & 0 & $\Delta$ & 0 & & & \\
\hline Type B' & & & 0 & & & 0 \\
\hline Type C & & 0 & & 0 & 0 & 0 \\
\hline
\end{tabular}

$\bigcirc=$ common $\Delta=$ present but rare.

compositional ranges of An 63-70 and An 53-68, respectively (Fig. 9). The high-An edges of these samples are about An 74, which is about An $8-10 \%$ higher than the core value.

In the Upper-Zone olivine gabbros, there is also no clear correlation between the core composition and the stratigraphic height. The maximum An value of the core composition (of Type B), however, seems to increase with stratigraphic height toward the upper chilled margin. Two samples from the middle of the Upper Zone (at 199 and 203 m levels) are particularly heterogeneous, containing plagioclases of Type $\mathrm{B}$ and Type $\mathrm{C}$ (Fig. 8).

\section{Discussion on the origin of plagioclase zoning}

\subsection{Lower Zone}

The sequence of events inferred from the zonal structure of plagioclase (Type A and Type B in particular) from the Lower
Zone, is (1) the formation of homogeneous calcic plagioclase (though some exceptionally show oscillatory zoning); (2) partial resorption of the calcic plagioclase accompanied (or followed) by the formation of the high-An edges; and (3) the formation of sodic mantle by plagioclase overgrowth. This scheme applies to all the plagioclase throughout the lower zone, both in the host olivine gabbros and the anorthosites, but the extent of resorption is greater in the latter. The latter is also characterised by a distinct compositional gap between the calcic core and the mantle (i.e., Type B, or B'), which may bear important implications for the origin of these structures. The processes of these events will be discussed sequentially below.

4.1.1. Formation of calcic plagioclase and the origin of the stratigraphic variations. The compositional constancy of the plagioclase core observed in the AC-subzone gabbros, including the 'phenocryst' in the lower chilled margin (Fig. 9), indicates that the calcic-core parts represent the original 


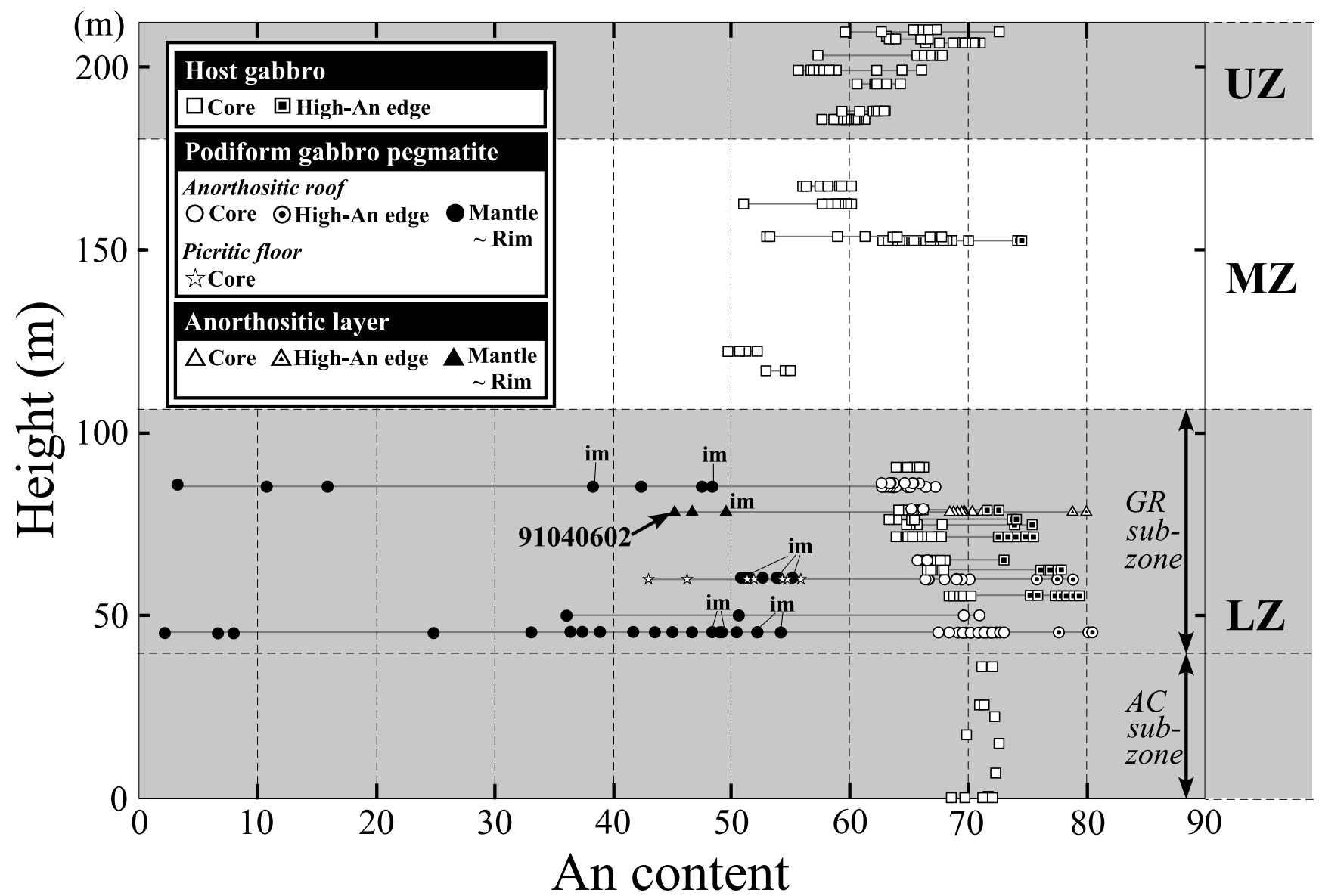

Figure 9 Stratigraphic variations of the plagioclase compositions throughout the Murotomisaki Gabbroic Intrusion. im=innermost mantle. The data of AC subzone are from Akatsuka et al. (1999). An exceptional sample, No. 91040602, is indicated by an arrow (see text).

plagioclase that was already present in the initial magma. It is remembered here that the size of the calcic core from the AC subzone is nearly the same as that of the phenocrysts in the chilled margin. The AC subzone was originally defined as the zone of crystal accumulation of olivine (Hoshide et al. 2006a), but the accumulation hypothesis may also apply to the plagioclase. The sodic mantle surrounding the calcic core, on the other hand, is considered to represent a postcumulus overgrowth as discussed below.

The vertical stratigraphic gradient of the plagioclase core composition in the GR subzone suggests that, in contrast to the AC subzone, some differentiation has taken place in the formation of this subzone (Fig. 9). Compositionally-uniform cores indicate that plagioclase crystallised without significant fractionation, which suggests that the effective size of the melt reservoir in equilibrium with the plagioclase was large enough and that the melt was thoroughly stirred. The vertical compositional gradient in the GR subzone, therefore, is interpreted to be a record of the melt composition evolved as the GR subzone grew (i.e., the upward migration of the boundary layer).

It is conceivable, therefore, that the GR subzone represents successively frozen magmatic boundary layers that have developed above the AC subzone. It was concluded from the observation of crystal grain size that olivine has grown significantly in the formation of the GR subzone (Hoshide et al. 2006a). Apparently, plagioclase has grown considerably as well. It was observed that, in the Lower Zone, olivine crystals are often partly included in the mantle of the plagioclase and are in contact with the outlines of the calcic cores (Figs 4c, 5a, $6 a)$. It is plausible, therefore, that the calcic plagioclase and olivine came closer during the crystal settling and 'collided' with each other (i.e., crystal impingement) before the plagioclase overgrowth, forming a crystal-supported 'framework structure'.

4.1.2. Resorption of calcic plagioclase and the formation of the high-An edges. The presence of hydrous phases, such as amphibole and chlorite at the embayments of the calcic cores, indicates that the resorption and probably the formation of high-An edges may have occurred in a hydrous environment that was created by the introduction (or fluxing) of $\mathrm{H}_{2} \mathrm{O}$. The resorption may occur when melt becomes undersaturated with plagioclase, and such a disequilibrium situation may be realised if $\mathrm{H}_{2} \mathrm{O}$ is introduced in the system as follows. An introduction of $\mathrm{H}_{2} \mathrm{O}$ would depress the liquidi (and solidi) of anhydrous phases such as plagioclase, olivine and cpx. Because the extent of the depression is greater for plagioclase than for olivine and cpx (e.g., McBirney 1987), the plagioclase field shrinks, and therefore, the liquid originally coexisting with olivine and plagioclase becomes undersaturated with these silicates and, therefore, plagioclase (and olivine as well) simply starts to dissolve (Fig. 10, the 'simple dissolution' of Tsuchiyama 1985). The source of $\mathrm{H}_{2} \mathrm{O}$ may be sought in the lower part of the boundary layer, because the $\mathrm{H}_{2} \mathrm{O}$ content in the melt increases rapidly as fractionation advances. More advanced resorption observed in the anorthosite implies more pervasive and extensive introduction of $\mathrm{H}_{2} \mathrm{O}$ there than in the host.

Following McBirney (1987), the present authors interpret the formation of high-An edges in the context of the hydrous crystallisation as follows. Suppose liquid $\mathrm{L}_{1}$ and plagioclase $\mathrm{S}_{1}$ once equilibrated (Fig. 10). When $\mathrm{H}_{2} \mathrm{O}$ comes in, both liquidus and solidus are depressed according to the introduced $\mathrm{H}_{2} \mathrm{O}$ 
(a)

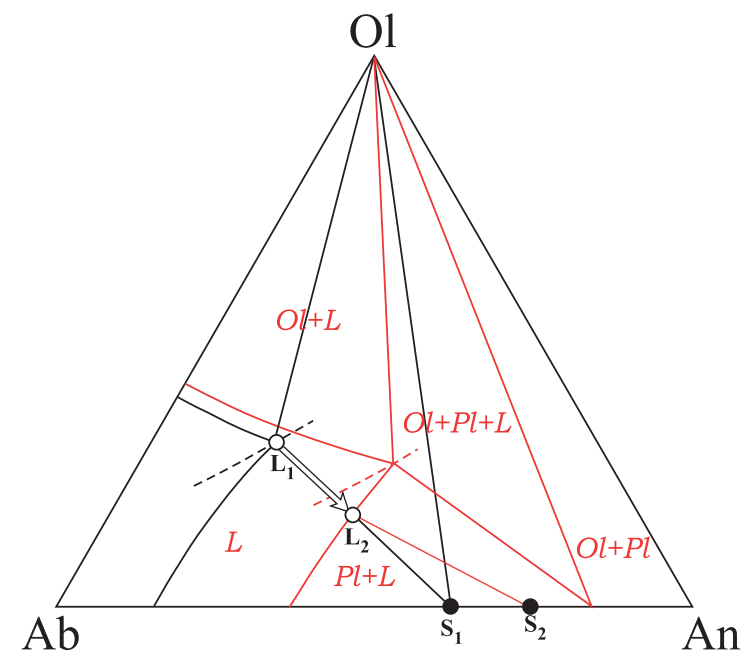

(b)

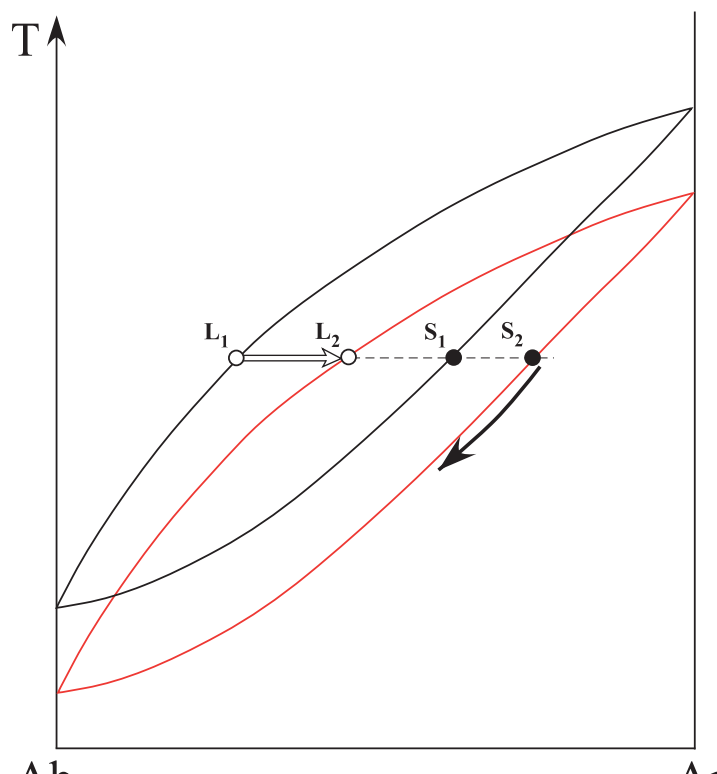

$\mathrm{Ab}$

An

Figure 10 (a) Isothermal sections of a hypothetical liquidus diagram of an olivine-Ab-An- $\left(+\mathrm{H}_{2} \mathrm{O}\right)$ system. Dry (black) and wet (red) isothermal sections at the same temperature and the same total pressure but of different activities of $\mathrm{H}_{2} \mathrm{O}$ are drawn for comparison. Each field is labelled for wet condition for clarity only. Projections of $\mathrm{Ol}-\mathrm{Pl}$ cotectic lines are partly drawn as dashed lines. When $\mathrm{H}_{2} \mathrm{O}$ is introduced in the dry system in which liquid $\mathrm{L}_{1}$ and plagioclase $\mathrm{S}_{1}$ were equilibrated, the original liquid $\mathrm{L}_{1}$ becomes undersaturated with plagioclase (and olivine) and the plagioclase $\left(\mathrm{S}_{1}\right)$ starts to dissolve, forming a thin film of hydrous liquid $\mathrm{L}_{2}$ on the surface of the dissolving plagioclase crystals. $\mathrm{L}_{2}-\mathrm{S}_{2}$ is an equilibrium tie line between the hydrated liquid and plagioclase. (b) Schematic projections of the plagioclase liquidus and solidus from $\mathrm{H}_{2} \mathrm{O}$ and olivine apexes onto the plagioclase-temperature plane. Dry (black) and wet (red) projections are compared. $\mathrm{L}_{1}, \mathrm{~L}_{2}, \mathrm{~S}_{1}, \mathrm{~S}_{2}$ are projections of those in the isothermal sections in (a). See text for more explanation.

content, and then the original liquid becomes undersaturated and so the plagioclase $\left(\mathrm{S}_{1}\right)$ starts to dissolve, forming a thin film of hydrous liquid $\mathrm{L}_{2}$ on the surface of the dissolving plagioclase crystals. The formation of liquid $\mathrm{L}_{2}$ makes a steep compositional gradient from the original composition $\mathrm{L}_{1}$, away from the plagioclase, toward $\mathrm{L}_{2}$ on the plagioclase surface. If the ambient temperature decreases faster than the elimination of this compositional gradient by diffusion in the melt, the new plagioclase that is precipitated on the dissolved plagioclase surface will be strongly zoned, reflecting this compositional gradient as follows. The first plagioclase to precipitate will be very close to $S_{2}$, which is in equilibrium with $L_{2}$ and is more An-rich than the original composition $\mathrm{S}_{1}$. Upon cooling, a sharp zoning will be formed from this $S_{2}$ toward composition $S_{1}$ which is in equilibrium with the original liquid $\mathrm{L}_{1}$, thereby forming the high-An edge. After that, normal zoning due to ordinary fractional crystallisation follows, which should show a gentler compositional slope than that in the high-An edge.

Dissolution of olivine as well as of plagioclase should occur when $\mathrm{H}_{2} \mathrm{O}$ comes in and, because of the shift of the olivineplagioclase cotectic line toward plagioclase, the original liquid enters into the olivine field (Fig. 10a) and then, upon cooling, olivine starts to grow before the liquid gets saturated with plagioclase again. It is probable that hydrous melts, which are now represented by amphibole clots, were those entrapped in these growing olivines. Similar amphibole-bearing clots have been observed in olivine, apatite and chromite crystals in many plutonic rocks (Boudreau et al. 1986; Boudreau 1999; Jakobsen et al. 2005; Li et al. 2005). Jakobsen et al. (2005) interpreted those amphibole clots in olivine from the Skaergaard Intrusion to represent trapped immiscible liquids at some early stages of fractionation. The similar occurrences and mineralogies of these amphibole clots may suggest that similar hydrous processes as advocated above for the Murotomisaki Gabbroic Intrusion (MGI) were operative in many plutonic environments.

Pringle et al. (1974) observed similar calcic edges of plagioclase in a diabase sheet from Grand Manan Island (Canada) and ascribed it to a large pressure drop when host magma ascended from a deep magma reservoir. However, such a hypothesis cannot be applied to the MGI, because the calcic cores of plagioclase in the MGI are generally larger than the plagioclase phenocrysts from the chilled margin and, therefore, the formation of the high-An edges must be after the emplacement of the magma. Certain pressure drop may occur in a magma reservoir if eruption occurs in overpressurised circumstances (e.g., Williams \& McBirney 1979). The observed compositional 'jump' of the high-An edge (about $10 \mathrm{An} \%$ ) corresponds to as much as $5 \mathrm{kbar}$ pressure drop (Takagi et al. 2005). This is too large to be accounted for by volcanic eruptions (Williams \& McBirney 1979). Similar high-An edges of plagioclase have also been described from the Skaergaard Intrusion by Maaløe (1976), who ascribed the feature to a disequilibrium overgrowth of plagioclase from supercooled magma. The supersaturation hypothesis has been employed to explain the oscillatory zoning of plagioclase (e.g., Sibley et al. 1976), but will not fit the explanation for such a sharp and single An-edge as observed in the MGI. An alternative hypothesis has therefore been presented for the MGI for the formation of high-An edges, combining the resorption by means of an introduction of $\mathrm{H}_{2} \mathrm{O}\left(\mathrm{H}_{2} \mathrm{O}\right.$ fluxing $)$ from the lower horizons of the boundary layer.

4.1.3. Origin of the sodic mantle. Overgrowth of the sodic mantle occurred after the resorption events described above. As emphasised above, the important difference between the host gabbro and the anorthosites in the GR subzone lies in the composition of the overgrown mantle of the plagioclase (Fig. $7 \mathrm{a}, \mathrm{b})$. Whilst the An-content gradually decreases from the core to the mantle of plagioclase in the host gabbro (Type A), it abruptly drops in the mantle in the anorthosites, marking a clear compositional gap at the edge-mantle boundary for the latter (Type B). The compositional gap in the plagioclase in the anorthosites may be ascribed to a discontinuous change in composition of the melt surrounding the plagioclase crystals. Such a change of melt composition cannot be explained by the introduction of $\mathrm{H}_{2} \mathrm{O}$ alone, as advocated above, and an additional introduction of fractionated melt components would be required. The introduction of the hypothetical fractionated melt was probably restricted to the anorthosite and 
(a)

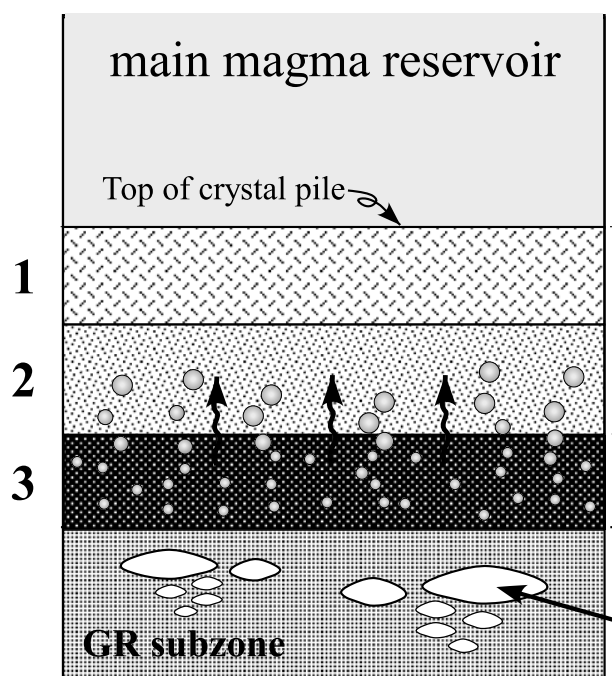

(b)

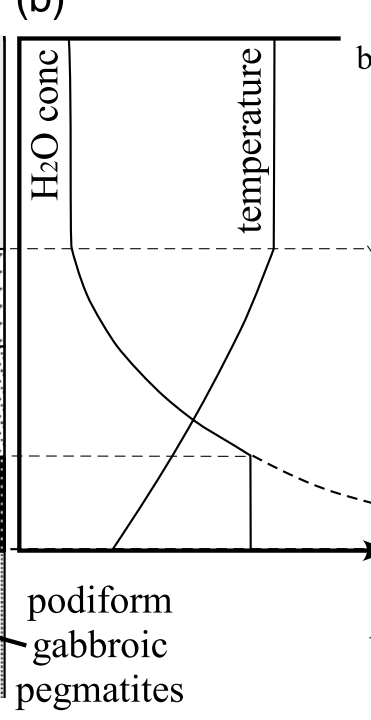

roof boundarylayer

Figure 11 (a) Schematic picture of a stratified basal boundary layer. The boundary layer is divided into three zones: Zone 1, plagioclase and olivine precipitate; Zone 2, hydrous flux melting and melt segregation (podiform gabbroic pegmatites and anorthosite layers); Zone 3, source of $\mathrm{H}_{2} \mathrm{O}$ and fractionated melts. See text for explanation. Thermal and $\mathrm{H}_{2} \mathrm{O}$ concentration gradients are only schematic. Fractionated melt reaches $\mathrm{H}_{2} \mathrm{O}$ saturation in Zone 3. (b) Advancing two boundary layers produce a stratified layered gabbro. gabbro pegmatites. In other words, the anorthosite and the gabbro pegmatites are the very sites that were preferentially attacked by the flux of fractionated melts accompanied by $\mathrm{H}_{2} \mathrm{O}$. The gentle An-decrease zoning in the mantle reflects subsequent fractional crystallisation that took place in the interstitial melts.

The source of this hypothetical fractionated melt is also sought in the lower part of the boundary layer (Fig. 11). It is conceivable that both $\mathrm{H}_{2} \mathrm{O}$ and fractionated melt come together from the same lower horizons. Fractionated melt will be enriched with $\mathrm{H}_{2} \mathrm{O}$, but considering the probable $\mathrm{H}_{2} \mathrm{O}$ saturated situation, it is likely that $\mathrm{H}_{2} \mathrm{O}$-rich fluids and the fractionated melt came together.

Plagioclase crystals from the picritic floor of the podiform gabbroic pegmatite hardly contain these calcic cores (Figs 6c, 7c). Their core composition is comparable to the mantle of the plagioclase from the anorthositic roof (Fig. 9). It is conceivable, therefore, that the crystallisation of plagioclase in the picritic floors took place concomitantly, maintaining chemical equilibrium with the mantle overgrowth of the plagioclase in the anorthositic roofs, i.e., after the invasion (or infiltration) of the fractionated melt. Similar to the plagioclase core in the anorthositic roofs, the olivine in the picritic floors has nearly the same composition as those in the adjacent host olivine gabbros. Therefore, it is conceivable that both the calcic plagioclase and the olivine formed together in the host gabbro and that they were separated and segregated when the fractionated melt came in.

\subsection{Middle Zone}

The Middle-Zone coarse gabbros contain three types of zoning, B, B' and C (Fig. 8, Table 1). Many plagioclases from the Middle Zone are more sodic than those from the Upper and Lower Zones (Type-C), while those in some samples (at the 152- and 153-m levels) are strongly calcic and have a homogeneous calcic core (Types B and $\mathrm{B}^{\prime}$ ). The Type $\mathrm{C}$ plagioclase may represents in-situ crystallisation products from the ambient fractionated melt. Type $\mathrm{B}$ and $\mathrm{B}^{\prime}$ plagioclases on the other hand must be exotic in origin. Because plagioclase with the high-An edges (i.e. Types A or B) cannot be found in the Upper Zone, the source of these plagioclases must be sought in the Lower Zone. Occurrence of the Type-B and B' plagioclase in the Middle Zone may be understood by considering the diapirism of anorthositic crystal mushes generated from the GR subzone below, as advocated by Hoshide et al. (2006b). In the samples containing Type-B and B' plagioclase, the Ancontents of plagioclase cores have a wide range amongst the different grains within one sample. This disequilibrium amongst the different grains suggests repeated supplies of diapiric anorthositic crystal mushes from the advancing basal boundary layer and incomplete magma mixing.

\subsection{Upper Zone}

The Upper Zone contains two types of zoning, B' and C (Fig. 8 and Table 1). In the Upper Zone, the maximum value of An-content of the plagioclase core (Fig. 9) has an apparently vertical gradient. Some of the plagioclases forming the vertical compositional gradient have compositional gaps between the cores and the mantles (i.e., Type- $\mathrm{B}^{\prime}$ ). The compositional gaps may suggest mixing between the crystal and the fractionated melt, as inferred for the Lower Zone. It is possible that the Type $\mathrm{B}^{\prime}$ plagioclase has its origin in the Lower Zone as in the Middle Zone, but full understanding of the origin and the processes of the Upper Zone must await further, more detailed, investigations of this zone.

\section{Segregation and diapirism of the anorthositic crystal mushes}

Another important effect of $\mathrm{H}_{2} \mathrm{O}$ is lowering the viscosity of silicate melt. The $\mathrm{H}_{2} \mathrm{O}$-charged flux-melting zone within the boundary layer may become fluid-dynamically unstable, because $\mathrm{H}_{2} \mathrm{O}$ effectively reduces the viscosity of silicate melt and thus increases the readiness of segregation in crystal mushes (McBirney 1987), causing an effective separation of lighter plagioclase crystals from the heavier olivine forming a modally graded layering (Fig. 2c), as observed in the base of the GR subzone. The podiform gabbroic pegmatite and the anorthosite may represent evolved forms of such a modallylayered structure. If the $\mathrm{H}_{2} \mathrm{O}$-enriched magma is segregated, forming a pod or layer, it will gain more buoyancy because the 
buoyancy is proportional to the volume of the masses, which would cause a gravitational instability. The wavy structure of the anorthosite roof and the upper surface of the anorthosite layer may be a manifestation of such instability. As crystallisation advances within the podiform gabbroic pegmatite, residual melt will become even more hydrous. This is consistent with the formation of pegmatitic filling between the anorthositic roof and the picritic floor, and also accounts for the observed coarsening of olivine crystals in the GR subzone. The occurrence of such buoyant hydrous melts in the anorthosite will enhance the buoyancy of the anorthositic magma and help the diapiric plume to develop. These plumes will eventually detach from their source, leaving the podiform gabbroic pegmatite with little anorthositic roof, as observed. The fact that the proportion of the anorthosite roof is very small in some podiform pegmatites (Fig. 3d) may indicate that substantial amounts of anorthositic magmas may have already escaped in the form of plumes from the site of their generation. The quantitative aspect of this process, i.e., the amount of the plume generated and the extent of its effect on the magmatic evolution, must be examined by studying mass balance using more extensive whole-rock data, which is a subject of future work.

\section{Summary and synthesis}

The processes deciphered from the analysis of the zonal structure of the MGI plagioclase may be summarised in the schematic picture in Figure 11. The whole process of the formation of the GR subzone (in the Lower Zone) may be understood in terms of a moving boundary layer in a crystallising magma body. The boundary layer, which contains steep thermal and chemical gradients, should be internally stratified in a steady state in three zones, 1, 2 and 3, as in Figure 11a. Zone 1, just beneath the crystallisation front, is that of crystal growth and crystal settling. Olivine and plagioclase steadily grow as the cooling advances and grown crystals will start to settle, probably leading to the 'crystal impingement'. Zone 2 is where $\mathrm{H}_{2} \mathrm{O}$-fluxed remelting and local crystal-melt segregation occurs, caused by the introduction of $\mathrm{H}_{2} \mathrm{O}$ and fractionated melts ascending from Zone 3 below. The modal layering, podiform gabbroic pegmatites and anorthositic layers were probably formed in this zone. Microscopically high-An edges formed around the resorbed plagioclase crystals upon further cooling. Zone 3 is the source of the $\mathrm{H}_{2} \mathrm{O}$ and hydrous fractionated melts which should be saturated with $\mathrm{H}_{2} \mathrm{O}$. Mixtures of $\mathrm{H}_{2} \mathrm{O}$-rich bubbles and fractionated melts probably rise together from this zone and get into Zone 2. Formation of the plagioclase sodic mantle and precipitation of augite occur in this zone. The compositional layering developed in the second layer will be frozen in this layer and, as the boundary layer migrates upward, accrete to the growing GR subzone just behind the moving boundary layer. Zone 2 is also a source of anorthositic crystal mush plumes, which may feed the main magma body above the boundary layer. The possibility that plagioclase crystals with high calcic cores (i.e., Type B and Type $\mathrm{B}^{\prime}$ ) found in the Middle Zones were derived from these anorthositic plumes was discussed previously.

This is a similar process to the 'constitutional zone refining' proposed by McBirney (1987) and Boudreau (1999), except for the diapiric ascent of anorthositic crystal mushes. $\mathrm{H}_{2} \mathrm{O}$ accumulation in Zone 2 is responsible for the segregation and formation of the compositional layering as originally proposed by McBirney (1987). Quantitative aspects of the effects of the ascending plumes generated from Zone 2 remains to be examined with more geochemical data.
The Upper Zone may have been formed at the same time by another moving boundary layer descending from the top of the magma body (Fig. 11b). However, the detailed processes in this descending boundary layer have not been discussed. The Middle Zone may represent the last layer of freezing sandwiched by these two moving boundary layers.

More detailed analysis of the Middle and Upper zones is necessary for a full understanding of the whole process of magmatic differentiation.

\section{Acknowledgements}

We are grateful to Dirk Spengler and Tetsuo Kawakami of Kyoto University for their discussions and critical reading of the manuscript and to A. Toramaru (Kyushu University) for valuable discussions in the field. We also acknowledge $\mathrm{T}$. Akatsuka for his permission for the use of unpublished data, and to H. Sato and U. Honma for arranging the electron microprobe facility at Venture Business Laboratory of Kobe University. The paper has benefited from critical and constructive criticisms of J. H. Bédard and R. A. Wiebe. This study was financially supported by a Grant-in-Aid for Research Fellow of the Japan Society for the Promotion of Science (No.19.4363) to TH.

\section{References}

Akatsuka, T., Obata, M. \& Yokose, H. 1999. Formation of layered structure in the Murotomisaki gabbroic complex, especially picrite gabbro, Kochi Prefecture, Japan-Quantitative evaluation of crystal accumulation. Journal of the Geological Society of Japan 105 (11), 771-88. [In Japanese with English abstract.]

Boudreau, A. E. 1999. Fluid Fluxing of Cumulates: the J-M Reef and Associated Rocks of the Stillwater Complex, Montana. Journal of Petrology 40, 755-72.

Boudreau, A. E., Mathez, E. A. \& Mccallum, I. S. 1986. Halogen Geochemistry of the Stillwater and Bushveld Complexes: Evidence for Transport of the Platinum-Group Elements by Cl-Rich Fluids. Journal of Petrology 27, 967-86.

Brandeis, G. \& Jaupart, C. 1986. On the interaction between convection and crystallization in cooling magma chambers. Earth and Planetary Science Letters 77, 345-61.

Costa, A., Blake, S \& Self, S. 2006. Segregation processes in vesiculating crystallizing magmas. Journal of Volcanology and Geothermal Research 153, 287-300.

Hamamoto, R. \& Sakai, H. 1987. Rb-Sr age of granophyre associated with the Muroto-misaki gabbroic complex. Science Reports of the Faculty of Science, Kyushu University, Geology 15 (1), 131-5. [In Japanese with English abstract.]

Hoshide, T., Obata, M. \& Akatsuka, T. 2006a. Crystal settling and crystal growth of olivine in the magmatic differentiation - the Murotomisaki Gabbroic Complex, Shikoku, Japan -. Journal of Mineralogical and Petrological Sciences 101, 223-39.

Hoshide, T., Obata, M. \& Akatsuka, T. 2006b. Magmatic differentiation by means of segregation and diapiric ascent of anorthositic crystal mush - the Murotomisaki Gabbroic Complex, Shikoku, Japan. Journal of Mineralogical and Petrological Sciences 101, $334-9$.

Jakobsen. J. K., Veksler, I. V., Tegner, C. \& Brooks, C. K. 2005. Immiscible iron- and silica-rich melts in basalt petrogenesis documented in the Skaergaard intrusion. Geology 33, 885-8.

Kodama, K., Taira, A., Okamura, M. \& Saito, Y. 1983. Paleomagnetism of the Shimanto Belt in Shikoku, southwest Japan. In Hashimoto, M. \& Uyeda, S. (eds) Accretion Tectonics in the Circum-Pacific Regions, 231-41. Tokyo: Terra Scientific Publishing Company.

Kodama, K. \& Koyano, T. 2003. Paleomagnetism and magnetic fabric of a mafic intrusive body and surrounding sedimentary rocks in the shimanto belt, southwest Japan: structural evolution of an accretionary prism recorded in magnetization of fore-arc intrusive rocks. IUGG 2003 Scientific Program Abstract, GAI.06. Sapporo, Japan: International Union of Geodesy and Geophysics.

Li, C., Ripley, E. M., Sarkar, A., Shin, D. \& Maier, W. D. 2005. Origin of phlogopite-orthopyroxene inclusions in chromites from 
the Merensky Reef of the Bushveld Complex, South Africa. Contributions to Mineralogy and Petrology 150, 119-30.

Maaløe, S. 1976. The zoned plagioclase of the Skaergaard Intrusion, East Greenland. Journal of Petrology 17, 398-419.

Mangan, M. \& Marsh, B. D. 1992. Solidification front fractionation in phenocryst-free sheet-like magma bodies. Journal of Geology 100, 605-20.

Marsh, B. D. 1988. Crystal capture, sorting, and retention in convecting magma. Geological Society of America Bulletin 100, 1720-37.

McBirney, A. R. 1987. Constitutional zone refining of layered mafic intrusions In Parsons, I. (ed) Origins of Igneous Layering, 437-52. Dordrecht, Holland: D. Reidel Publishing.

Pringle, G. J., Trembath, L. T. \& Pajari, G. E. 1974. Crystallization history of a zoned plagioclase. Mineralogical Magazine 39, 86777.

Sibley, D. F., Vogel, T. A., Walker, B. M. \& Byerly, G. R. 1976. The origin of oscillatory zoning in plagioclase; a diffusion and growth controlled model. American Journal of Science 276, 275-84.
Tait, S. \& Jaupart, C. 1992. Compositional convection in a reactive crystalline mush and melt differentiation. Journal of Geophysical Research 97, 6735-56.

Takagi, D., Sato, H. \& Nakagawa, M. 2005. Experimental study of a low-alkali tholeiite at 1-5 kbar: optimal condition for the crystallization or high-An plagioclase in hydrous arc tholeiite. Contributions to Mineralogy and Petrology 149, 527-40.

Tsuchiyama, A. 1985. Dissolution kinetics of plagioclase in the melt of the system diopside-albite-anorthite, and origin of dusty plagioclase in andesites. Contributions to Mineralogy and Petrology 89, $1-16$.

Turner, J. S., Huppert, H. E. \& Sparks, R. S. J. 1986. Komatiites II: Experimental and theoretical investigations of post-emplacement cooling and crystallization. Journal of Petrology 27, 397-437.

Williams, H. \& McBirney, A. R. 1979. Vulcanology. San Francisco, California: Freeman, Cooper. 397 pp.

Yajima, T. 1972. Petrology of the Murotomisaki gabbroic complex. The Journal of the Japanese Association of Mineralogists, Petrologists and Economic Geologists 67, 218-41.

MS received 30 November 2007. Accepted for publication 16 May 2008 (Stellenbosch); 15 January 2009 (RSE). 
